\title{
Flora of Brazil Online: Can Brazil's botanists achieve their 2020 vision?
}

\author{
Marli Pires Morim ${ }^{1} \&$ Eimear M. Nic Lughadha ${ }^{2}$
}

\begin{abstract}
This paper seeks to provide an assessment of the prospects of delivering an online Flora of Brazil by 2020 . Our approach is to evaluate the nature and extent of documentation of the Brazilian flora over the past 15 years before exploring whether existing botanical documentation and capacity is sufficient to support the production of a complete Flora over a five-year period. We address the following 'headline' questions: Has a high proportion of Brazilian species been described? Are collection densities sufficient to underpin a national Flora? Is there sufficient botanical expertise available to execute such a big project over a five-year period? Are there current taxonomic treatments that support the development of a national Flora? The results obtained show that the proportion of the flora estimated to have been described is high enough to be confident that those preparing Flora treatments will not be overwhelmed by the numbers of species new to science requiring description; the national average of 1.08 specimens per $\mathrm{km}^{2}$ is significant; relevant taxonomic treatments with a variety of different scopes and geographic scales are available; and, finally the botanical expertise available is demonstrated by the results presented in the List of Species of the Flora of Brasil.
\end{abstract}

Key words: Angiosperms, herbaria, Reflora, sampling, Taxonomic.

\begin{abstract}
Resumo
Este trabalho visa fornecer uma avaliação das perspectivas de concluir a Flora do Brasil on-line até 2020. Nossa abordagem é avaliar a natureza e a extensão da documentação da Flora Brasileira ao longo dos últimos 15 anos, antes de explorar se a documentação e capacidade botânica existentes são suficientes para apoiar a produção de uma Flora completa no período de cinco anos. Nós abordamos as seguintes questões temáticas: há uma proporção elevada de espécies brasileiras já descritas? A densidade de coleta é suficiente para sustentar uma Flora Nacional? Há expertise botânica disponível o bastante para executar um projeto tão grande ao longo de um período de cinco anos? Existem tratamentos taxonômicos atuais que apoiem o desenvolvimento da Flora Nacional? Os resultados obtidos mostram que a proporção da flora que se estima já ter sido descrita, é alta o suficiente para se ter a certeza de que os tratamentos destinados à elaboração da Flora não serão subjugados por números de novas espécies para a ciência necessitando de descrição; a média nacional de 1,08 espécimes por km² é significativa; tratamentos taxonômicos relevantes com uma variedade de diferentes escopos e escalas geográficas estão disponíveis; e, finalmente, a expertise botânica disponível é demonstrada pelos resultados apresentados na Lista de Espécies da Flora do Brasil.

Palavras-chave: Amostragem, Angiospermas, herbários, Reflora, Taxonomia.
\end{abstract}

\section{Introduction}

Early impressions of and interest in Brazilian plant species and vegetation formations are reported by european visitors at the time of the 'discovery' of Brazil (Andrade-Lima 1984; Filgueiras \& Peixoto 2002). In his botanical analysis of the letter of Pero Vaz de Caminha to the Portuguese king D. Manoel I, Andrade-Lima (1984) highlighted the observation "..the plants were seen before the land...". Reports, iconographic records, specimens and scientific expeditions to various regions of Brazil documenting the Brazilian flora all evidence the extensive research undertaken by naturalists from the $17^{\text {th }}$ to $19^{\text {th }}$ Centuries (Giulietti \& Forero 1990; Peixoto 1999). Some 340 years after the discovery of the country by Europeans, publication

\footnotetext{
Instituto de Pesquisas Jardim Botânico do Rio de Janeiro, R. Pacheco Leão 915, 22460-030, Rio de Janeiro, RJ, Brasil. mpires@jbrj.gov.br

${ }^{2}$ Conservation Science Department, Royal Botanic Gardens, Kew, Richmond, United Kingdom. e102kg@kew.org
} 
of the first national Flora began: Flora Brasiliensis described 19,958 species including algae, fungi and plants (Martius et al. 1833; Urban 1906).

Completing a national Flora of any country is an audacious objective in which many years of work are often invested in order to achieve the goal. The probability of success with such a task, and the complications and obstacles likely to be encountered while completing a national Flora depend on diverse factors, but three key considerations come to mind immediately which must form part of any such evaluation: (i) the geographical extent of the area to be treated by the Flora, (ii) the levels of richness and diversity of the species occurring therein and (iii) the available knowledge about these species. Considering these three primary parameters, the preparation and completion of a Flora of a large and megadiverse country in which many plant species remain to be discovered can be seen as an even greater challenge.

Brazil is located in the Neotropical region which encompasses c. $40 \%$ of the terrestrial surface of the earth and is home to a surprisingly large number of living organisms (Forero \& Mori 1995). Brazil's vast area $\left(8,515,767 \mathrm{~km}^{2}\right.$, IBGE 2015) makes it the largest country in the Neotropics. Of the six phytogeographic domains or biomes occurring within Brazil: Amazônia, Cerrado, Caatinga, Mata Atlântica, Pampa and Pantanal, two are recognised as global biodiversity hotspots: Cerrado and Mata Atlântica (Mittermeier et al. 1998; Myers et al. 2000).

These six phytogeographic domains represent a broad diversity of vegetation types, resulting from biotic and abiotic factors which influenced the history and evolution of the neotropics (Antonelli \& Sanmartín 2011). In this context, it can readily be understood why the Brazilian flora has the greatest diversity of vascular plants of any country in the world (Forzza et al. 2010, 2012; BFG 2015). This unrivalled plant diversity encompasses an extraordinary variety of habits, life-forms and biological associations ranging from species confined to particular environments on different geographical scales to more generalist taxa with broader distributions, which often exhibit great morphological plasticity across their range.

Authoritative, reliable taxonomic identification of species is fundamental to understanding species diversity and richness of life on earth, as well as providing the basis for defining conservation strategies consistent with rational use of natural resources and sustainable development (Trias-Blasi \& Vorontosova, 2015). Efforts invested in floristic surveys, Flora treatments and monographs dealing with a whole family, genus or infra-generic group, and the biological collections associated with these activities are the primary sources for our knowledge of plant biodiversity (Thomas et al. 2012).

The Convention on Biological Diversity (CBD 1992) had a marked impact on the perceived importance of biodiversity and on the regulation of access to biodiversity, as well as on the treatment of scientific questions relating to biodiversity. The scientific quest of researchers to estimate the number of plant species on earth, a concern shared by naturalists since the time of Linnaeus (1753 apud Forzza et al. 2010), was combined with the international committments made by the signatories to the CBD in addressing targets envisaged to reach the primary objectives of the convention the conservation of biological diversity, the sustainable use of its components and the fair and equitable sharing of the benefits arising from the utilization of genetic resources.

The Global Strategy for Plant Conservation, designed to accelerate knowledge and conservation of plants within the framework of the CBD, defined 16 targets to be attained by 2010 . The first of these targets was the preparation of a widely accessible working list of all known plant species, as a step towards a world flora (Nic Lughadha 2004).

Fulfilling the committment assumed by Brazil through the GSPC in relation to the national list of species certainly provided a major motivating incentive for Brazilian taxonomists. To meet this challenge c. 413 taxonomists worked in a network from October 2008, and 21 May 2010 saw the online launch of "Lista de espécies da flora do Brasil" and the subsequent publication of "Catálogo de fungos e plantas do Brasil" (Forzza et al. 2010): covering 40,989 species of plants and fungi, of which 18,932 (46.2\%) were reported to be species endemic to Brazil. Details on the development of the Brazilian List and comparative analyses of the different major taxa, levels of richness and endemism in Brazil and globally, are provided in Forzza et al. $(2010,2012)$.

Having met the GSPC Target 1 in 2010, the team of taxonomists did not consider their census of Brazilian plant species complete. They envisaged the Brazilian List as a dynamic resource, bearing in mind that, in taxonomic science, new information 
is discovered on a daily basis concerning species already described, not to mention the many species new to science still being discovered and described. The Brazilian List process continued from 2010 through to March 2015 with later versions of the online resource being greatly enriched with ecological data as well as updates on taxonomy and distribution. Results to date for all the groups of plants and fungi treated are available in BFG (2015), Costa \& Peralta (2015), Maia et al. (2015), Menezes et al. (2015) and Prado et al. (2015).

The same period saw the establishment by "Conselho Nacional de Desenvolvimento Científico e Tecnológico" (CNPq) of the Reflora Programme and the creation of the Reflora Virtual Herbarium $(<$ http://reflora.jbrj.gov.br/>). The Brazilian List became an integral part of the Reflora programme and there was a large increase in the numbers of specimen images linked to vouchers for names. As well as the images originating from the databases of the herbarium of the Rio de Janeiro Botanical Garden (RB) and the Virtual Herbarium of Flora and Fungi (INCT), hundreds of thousands of images from the herbaria of the Royal Botanic Gardens, Kew (K) and the Muséum National d'Histoire Naturelle in Paris (P) were also made available within the framework of Reflora. Subsequently, further new partnerships resulted in contributions from the following Brazilian and overseas herbaria, all of which are now incorporated in the Reflora framework: UFRN, EAC, ASE, ALCB, CEPEC, VIES, HUFU, ESA, CEN, UPCB, MBM, FLOR, HBR, HDCF, RON, $\mathrm{MG}, \mathrm{S}, \mathrm{NY}, \mathrm{MO}$ and $\mathrm{W}$.

Encouraged by the success of the target setting approach, of which the GSPC was a pioneering example (Paton \& Nic Lughadha, 2011), at its tenth meeting, in Nagoya, Japan in October 2010, the Conference of the Parties to the CBD adopted a revised and updated version of the GSPC, with new targets to be achieved by 2020 . Where the original Target 1 had called for 'a widely accessible working list of all known plant species, as a step towards a world Flora', the revised Target 1 called for 'An online Flora of all known plants' to be delivered by 2020 . The technical rationale suggested that important steps towards this objective might include developing more complete synonymy; updating geographic distributions, inclusion of basic identification tools (keys, picture and basic descriptions) and inclusion of local and vernacular names where possible (Executive Secretary to the Convention on Biological Diversity 2010).
It is by no means coincidental that several of the tasks undertaken between $2010-15$ by the network of botanists committed to enhancing the Brazilian List are exactly those required to convert a Checklist into a Flora. As we write, in May 2015, levels of confidence and enthusiasm among Brazilian botanists at the prospect of completing a national Flora are manifestly high and groups of specialists are preparing plans to work together to tackle particular groups. While confidence and enthusiasm are valuable commodities at the outset of any project, they need to be balanced with a critical assessment of the resources available versus those that may be required and an evaluation of the lessons learned from similar endeavours in Brazil and elsewhere.

This paper is intended as a contribution towards the enormous challenge of completing a Flora of Brazil by 2020 by considering (i) the experiences of the past seven years since the Brazilian List was initiated, (ii) the knowledge acquired and the resources mobilised in the preparation of the Brazilian List and (iii) the state of documentation of the flora and the human capital and taxonomic infrastructure required for the next phase.

We do not attempt a comprehensive treatment of the sort that might be included in a feasibility study but rather address the following broad 'headline' questions: Has a sufficiently high proportion of Brazilian species been described to justify attempting a national Flora? Are collection densities sufficient to underpin a national Flora? Is there sufficient botanical expertise available to develop such a big project over a five-year period? Are there current taxonomic treatments which support our understanding of the morphological variation of Brazilian plant species?

\section{Methods}

For each of the headline questions in our review we framed a series of more specific, narrowly-focused questions designed to address particular facets of the headline question. We then sought quantitative and/or qualitative data to address each of these specific questions. We focused primarily on angiosperms as they account for the vast majority of the known species in the Brazilian flora.

For concepts and boundaries of biomes we followed IBGE 2004. Our analyses of 
angiosperm species in the Brazilian List were based on the results presented in BFG (2015).

Proportion of flora already known

Underlying our headline question "Has a sufficiently high proportion of Brazilian species been described to justify attempting a national Flora?", we identified the following quantitative and qualitative questions: What proportion of Brazilian angiosperms is estimated to have been described/discovered to date? How many remain to be described? How many are already known to science but yet to be discovered within Brazilian borders? Will the ongoing description of new species disrupt or assist the development of the national Flora?

We first derived estimates of the proportions of Brazilian angiosperm species described to date and awaiting discovery/description. We adapted the approach adopted by Pimm et al. (2010) which was based on partial lists of angiosperm species endemic to a single region of Brazil derived from the World Checklist of Selected Plant Families. We extended their approach to the more up-to-date and comprehensive species listing in the Brazilian List (BFG 2015) to obtain estimates of the number of angiosperms endemic to a single region awaiting discovery/description. To check the validity of our extrapolation we compared the relative numbers of species analysed by Pimm et al. (2010) for different regions of Brazil to equivalent numbers for angiosperms as a whole and for Apocynaceae, recently shown to have species richness distribution exceptionally highly correlated with the species richness distribution of Brazilian angiosperms as a whole (Pugliesi \& Rapini 2015).

We used the estimates of single-region endemic angiosperms awaiting discovery to predict the number of other additions to the flora, of species already known to science but not previously reported from Brazil. In light of results of parallel analyses (BFG 2015), we assumed that the proportion of endemic angiosperm species would remain relatively stable as knowledge of the flora increases i.e. that for every 100 species added to the flora, c. 57 would be Brazilian endemics while c. 43 would be species already known from other countries. If this proportion remains stable then the number of non-endemic additions to the flora could be predicted from the number of newly described endemics by applying the ratio 1:0.75.

We used a sample of data from the International Plants Names Index (IPNI) to quantify recent rates of addition of species new to science described from Brazil from 2010 to 2014 inclusive and evaluate the likely impact of future additions on the preparation of the Flora over a five-year time-scale.

\section{Sampling sufficiency}

To address the headline question "Are collection densities sufficient to underpin a national Flora?", we identified the following underlying questions: What collection density is considered sufficient? What is the current collection density? How does collection density vary across Brazil?

We consulted 155 entries for Brazilian herbaria in Index Herbariorum (Thiers [continuously updated]). We also contacted curators of herbaria located beyond the borders of Brazil which are known to hold important collections of Brazilian material and obtained estimates of their total Brazilian holdings (BM, BR, K, M, MO, MPU, NY, US) as well as those of several smaller German herbaria (Hajo Esser pers comm.). We collated these data to obtain approximations of the numbers of specimens of Brazilian plants in the world's herbaria and the mean number of specimens per square kilometre. We compared these estimates with thresholds of 'collection density' (numbers of herbarium specimens per $100 \mathrm{~km}^{2}$ ) commonly cited for sampling sufficiency in tropical countries (Campbell 1989) and (Shepherd 2003), and with equivalent figures at global level and for other tropical countries where national flora initiatives are already in progress. We also compared the totals for Brazilian herbaria to equivalent figures reported by Sobral \& Stehmann (2009) for 1990 and 2006 to provide an estimate of rates of growth in specimen numbers over the past 25 years. We analysed the totals for Brazilian herbaria by region to estimate collection densities for areas of scale more comparable to those of other national Flora projects and compared the resulting totals to equivalent data compiled from Index Herbariorum by Barbosa \& Peixoto (2003). It is important to note that these regional analyses report numbers of specimens deposited in each major region, not all of which will have been collected in that region.

Finally, to facilitate consideration of the results for Brazil in a global context we calculated the mean number of herbarium specimens per $\mathrm{km}^{2}$ at global level using the estimate of 350 million specimens reported in Index Herbariorum and the 
terrestrial surface of the earth at c. 149 million square kilometres.

\section{Taxonomic capacity}

Unpacking our headline question: 'Is there sufficient botanical expertise available to develop such a big project over a five-year period?,' we identified the following underlying questions: Does sufficient relevant botanical expertise exist? Where is it located? What will determine its availability for this project? What competing priorities are there for botanists?

To gauge the scale of existing botanical expertise of direct relevance to the Flora of Brazil we relied on the experience gained during the delivery of the Brazilian List in 2010 and subsequent enhancements (BFG 2015). We obtained data on the composition of the team that delivered this project and compared them with those analysed by Sobral \& Stehmann (2009) on the publication of new species from Brazil over the period 1990-2006.

Finally, we undertook a more detailed analysis of some of the new species published from Brazil over the period 1992-2010 to detect changes over time in the geographical location of taxonomic effort applied to the Brazilian flora. The sample used was developed for a larger study (Cowling et al. in prep.) and comprised 50\% of the names reported in the IPNI as being published during each of two three-year intervals: 1992-94 and 2008-2010. Within this sample we considered authors of new species described from Brazil over two 3-year periods: 1992-1994 and 2008-2010. For each of these names we determined the country in which the author was based when the work was undertaken (as reported in the protologue). We then compared the numbers of Brazil-based authors for the two time-periods.

To evaluate these data in a global context we considered numbers of species and numbers of botanists for three major tropical floras, two in progress (Flora of Cameroon, Flora of Thailand) and one recently completed (Flora of Tropical East Africa). We calculated the number of species per botanist and, where applicable, number of species per botanist per year.

\section{Building on existing treatments}

To evaluate the extent to which the new national Flora can be developed based on existing treatments we first framed the rather broad question: Are there current taxonomic treatments, produced in the $21^{\text {st }}$ Century, which support our understanding of the morphological variation of Brazilian plant species? The specific underlying questions here are: How many taxonomic revisions of Brazilian plant families and/or genera have been produced? What is the coverage of Floras treating Brazilian species? What proportion of the species in the Brazilian List have been treated in a Brazilian state Flora?

The 'Bibliographic Reference' field of the Brazilian list (BFG 2015) was our main source of evidence for the production of taxonomic revisions and synopses and of Floras. For this first survey we focused on the years from 2000 to the present, a period during which major changes in the circumscription of taxa were frequent as a result of molecular and phylogenetic studies. We counted complete taxonomic revisions of families, partial revisions (e.g. of sections of genera, tribes and subfamilies) and synopses. Based on the compiled information we estimated the number of species treated in these revisions by consulting the published article or the author. Where neither of these approaches was feasible (chiefly in the case of doctoral theses and masters dissertations as yet unpublished) we assumed that the number of species treated in the revision was the same as the number of species recognised in Brazilian List.

Based on the survey we chose five Floras to illustrate the extent of knowledge of Brazilian plants at different geographical scales and in different Brazilian biomes. Quantitative data on the species covered to date by each of these Floras were obtained as follows. For the monographic series Flora Neotropica, we consulted monographs published for angiosperm taxa known to occur in Brazil and checked the 'Numerical List of Taxa' to obtain the total number of species treated (Organization for Flora Neotropica Monograph 1967-2007). Quantitative data on Flora Neotropica published from 2010 to 2014 inclusive were supplied by the editor (Thomas pers. comm.). For each taxon that had been monographed, the corresponding number of Brazilian species was obtained from the BFG (2015). For the Flora Ilustrada Catarinense (Reitz 1965-1989; Reis 1996-2005) we consulted the "CONSPETO GERAL" (General Conspectus) for each of the volumes online at "Enciclopédia Flora Ilustrada Catarinense" (<http://hbriai.webnode. com.br/news/fic/ $>$ ) and we selected the families 
of angiosperms native to Brazil. In the case of the Flora Fanerogâmica de São Paulo we obtained quantitative data on families, genera and species from Wanderley et al. (2011). Similarly, for Flora of Sergipe, quantitative information were obtained from Prata et al. (2013). Finally for the Flora of the Distrito Federal, quantitative information on treatments published to date were obtained from the editors (Cavalcanti \& Ramos 2001; Andrielli C. A. Lopes pers.comm.).

In order to evaluate the extent of overlap in coverage of species between these State Floras, we conducted pairwise comparisons of species lists for three plant families each of which had been treated in more than one of the Floras. For this purpose we chose two families which we expected to represent the extremes of variation in overlap and one which we expected might be broadly representative of angiosperms more generally. We selected Myrtaceae, a family well known for having many species with restricted distributions in Mata Atlântica (Murray-Smith et al. 2009), Poaceae which includes many widespread species (Longhi-Wagner et al. 2001), and Apocynaceae which was recently shown to have species richness distribution exceptionally highly correlated with the species richness distribution of Brazilian angiosperms as a whole (Pugliesi \& Rapini 2015). For each comparison, we summed the number of species reported for each state (gross total) and subtracted the number of species reported as occurring in both states (net total). Dividing net by gross totals gives an indication of the amount of overlap in species between state Flora treatments of the same family, with a value close to 1 indicating little overlap while values close to 0.5 would reflect susbtantial overlap.

\section{Results}

Proportion of flora already known

Consulting the Brazilian List we noted almost 12,000 species $(11,973)$ which were reported to be endemic to one of the five major administrative regions of Brazil. Numbers of single-region endemics ranged from just over 1,000 in the South to 5,690 in the South East (Tab. 1). The numbers of single region endemics considered by Pimm et al. (2010) were very highly correlated with those reported by the Brazilian List for Apocynaceae $\left(\mathrm{r}^{2}\right.$ $=0.99)$ and for angiosperms $\left(r^{2}=0.99\right)$. Applying the percentage increases per region predicted by the Pimm et al. (2010) model to these more comprehensive numbers for regional endemics yielded estimates for single-region endemics awaiting discovery/description ranging from 246 species for Centre-West and South regions to 1,179 for Northeast Brazil. Summing these regional estimates gave a national total of 2,618 angiosperm species endemic to a single region and still awaiting discovery/description (Tab.1).

Assuming the proportions of endemic and non-endemic elements of the flora remain stable over time, an assumption broadly in line with results reported in parallel analyses (BFG 2015), then we can predict that the number of non-endemic species awaiting discovery in Brazil is c. 1,963 species. Summing predicted additions of singleregion endemics and non-endemic species gives a total predicted growth in the flora of 4,581 species, equivalent to a $14 \%$ increase in species numbers against the baseline total of 32,086 angiosperm species reported in BFG (2015). In other words our analysis suggests a total angiosperm diversity in Brazil of 36,666 species of which $88 \%$ are already known to science and recorded from Brazil.

Records of species described as new to science with types from Brazil totalled 1,191 over the five-year period 2010-2014, thus averaging 238 per annum (see BFG 2015 for further details).

\section{Sampling sufficiency}

Of the 155 Brazilian herbaria for which entries were consulted, 137 are current repositories for Brazilian specimens. The total number of specimens reported to Index Herbariorum by these herbaria was 6,697,000 (hereafter rounded to 6.7 million, Fig.1). This figure includes material collected in countries other than Brazil but deposited in Brazilian herbaria. A breakdown by country was not possible, but our experience is that non-Brazilian material contributes only a very small proportion of the total material. For example, in RB, one of the most international of Brazil's herbaria, only $6 \%$ of the material is from countries other than Brazil (Luis Alexandre Estevão da Silva pers. comm.) and much lower proportions of non-Brazilian material would be typical of most Brazilian herbaria (Forzza pers. comm.) While a figure for total holdings in Brazilian herbaria certainly overestimates holdings collected in Brazil, this may be offset in part by the fact that many Brazilian herbaria do not update their entries in Index Herbariorum with great regularity, thus published figures for herbarium holdings inevitably 
lag behind actual figures. In the case of the rapidly growing herbarium RB, some 130,000 specimens had been added to the collection since the last update, a figure we added to our estimate, giving a total of 6.8 million for use in collection density estimates (Tab. 3).

Analysis of these Brazilian repositories by region showed a very skewed distribution (Tab. 2), with the vast majority of the collections deposited in the South and Southeast and little change between 2003 and 2015 in terms of the regional distribution of the collections.

The combined estimates of the Brazilian holdings in European herbaria for which we could obtain data exceeded 1.3 million while the collections of just three major US herbaria together account for a further million specimens (Tab. 3). Combining these estimates we obtained a total of 9.2 million Brazilian specimens, equivalent to 1.08 specimens per square kilometer of Brazil's 8,515,767 km² extent.

The calculated global mean of 2.4 specimens per $\mathrm{km}^{2}$, exceeds the threshold of one specimen per $\mathrm{km}^{2}$ proposed by Campbell (1989) and approaches that of three specimens per $\mathrm{km}^{2}$ suggested by Shepherd (2003). Equivalent values for other tropical countries with Flora projects in progress were estimated at 0.82 for Cameroon and calculated for Thailand at 0.96 (See Tab. 4 for sources).

It is important to note that all of the above estimates are for numbers of specimens (typically comprising a single herbarium sheet) rather than for numbers of collections (which typically comprise several specimens, usually distributed to several different herbaria and thereafter counted as separate specimens). This approach is necessary in

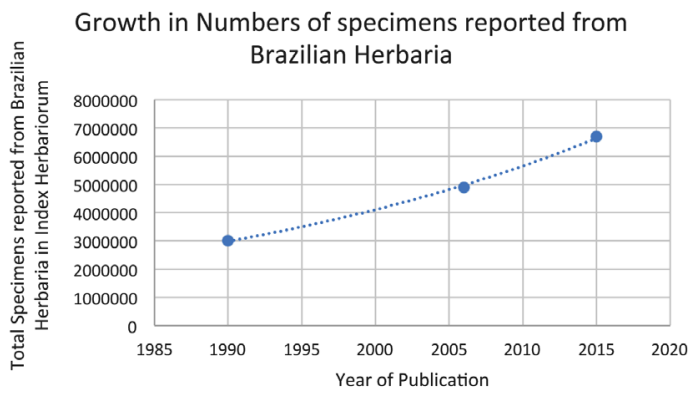

Figure 1 - Change over time in total numbers of specimens reported in Index Herbariorum as deposited in Brazilian Herbaria. order to facilitate comparison with earlier studies and due to the limitations of the data available.

\section{Taxonomic capacity}

A total of 413 collaborators were involved in the preparation of the Brazilian List (Thomas et al. 2012). Of these, 413 scientists, the vast majority (86\%), were reported to be Brazilian. A similar number of scientists, 483 in total, were reported by Stehmann \& Sobral (2009) as having been involved in the description of new species from Brazil over the period 1990-2006, but just 43\% (209) of these authors were reported to be Brazil-based (Tab. 5).

More detailed analysis of 50\% samples of IPNI data for 1992-1994 and 2008-2010 showed that four times as many Brazilian species new to science were described by Brazil-based botanists over the later time period than in the earlier one. There was also a marked increase in the number of Brazil-based botanists participating in the process of description of new species, with more than three times as many individuals involved in the publication of at least one species new to Brazil during 2008-10 as were involved in 1992-94 (Fig. 2).

Comparing species numbers, timescales and human resources for the Brazilian flora with those for other tropical flora projects in progress or completed (Tab. 6) indicated that the number of species to be treated each year would be several times higher than the rate recently proposed for another project considered ambitious in timescale (Flora of Thailand) and many times higher than the annual rates achieved for the only tropical Flora of $>10,000$ species completed this century (Flora of Tropical East Africa). However, when the scale of the trained taxonomic capacity potentially available is factored in - we used the figure for the collaborators involved in the most recent round of enhancements to the Brazilian List (BFG 2015) the numbers of species treatments to be completed per person per year are 'just' twice those projected for Flora of Thailand.

\section{Building on existing treatments}

For the period under review (2000-early 2015) authors of the Brazilian List cited c. 168 taxonomic revisions at diverse taxonomic ranks. Notably, these include seven revisions at family level, treating all known Brazilian species of, respectively, Apodanthaceae, Balanophoraceae, Canellaceae, Cannaceae, Caryophyllaceae, Heliconiaceae and Rhamnaceae. Included in this 

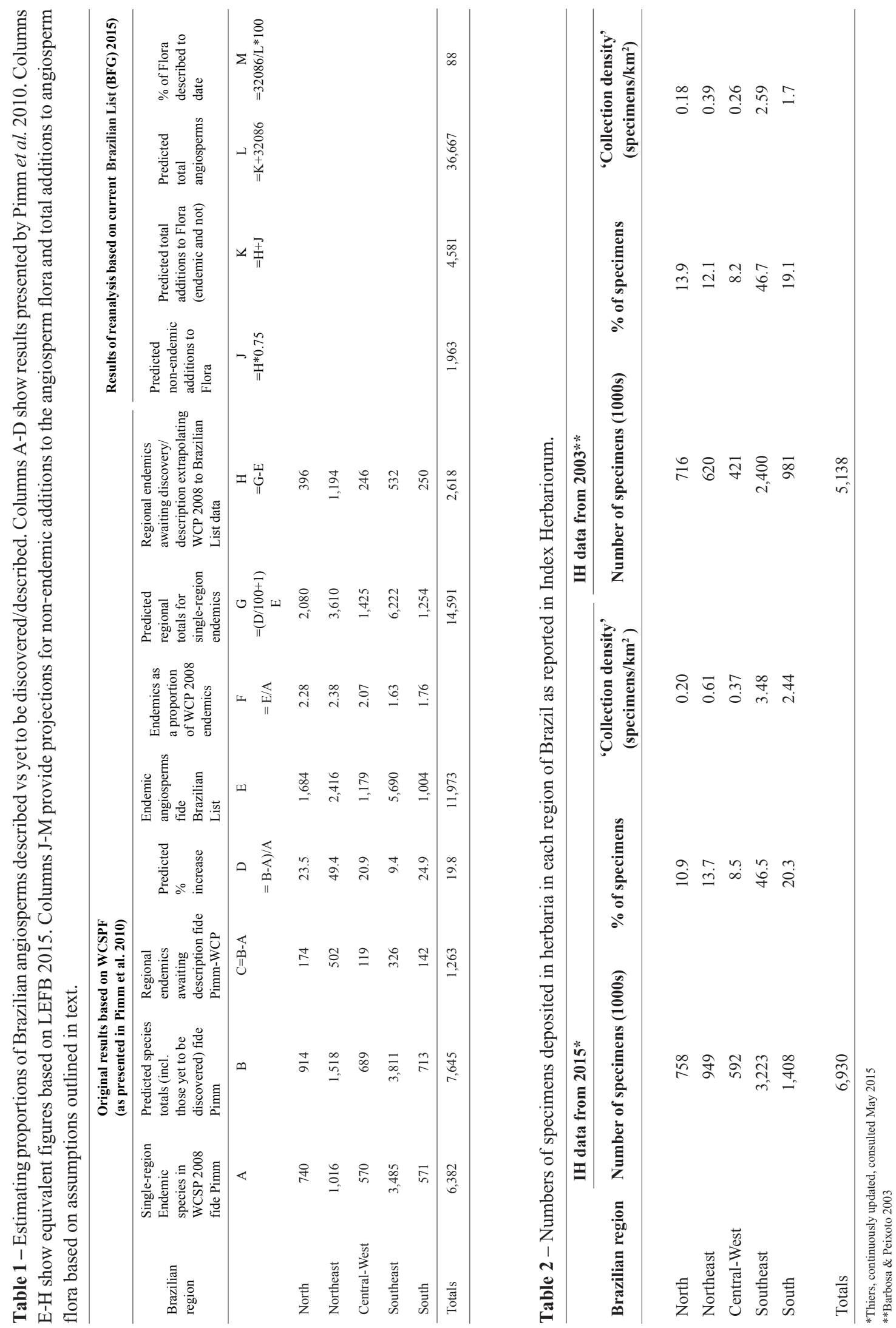
large set of recent revisions are several theses with submission dates of 2005 or later. Collectively the revisions treat c. 2,186 Brazilian species.

The authors included 1,341 references to Flora treatments (including multiple citations of the same Flora treatment). Although the data are not available in a suitable format to derive numbers of different Flora treatments cited, nor the number of species they treat, they do provide a good overview of the differing geographic scopes, of the diversity of Floras and of the qualitative information they offer about Brazilian species, which we address further in our Discussion, along with the quantitative results presented below.

Among the Floras cited by the Brazilian List taxonomists, one of the most cited is that with the greatest geographical scope, the Flora Neotropica monograph series, which has been published since 1967, and documents the great richness and diversity of the plants of the different vegetation formations of the Neotropics. Of the 114 Flora Neotropica volumes published to date, 84 treat angiosperm families or genera and collectively these cover a total of c. 7,532 species. The vast majority ( 81 of the 84 monographs) include angiosperm species which occur in Brazil. Over the period 2000-2014, a total of 23 Flora Neotropica monographs were published, treating 1,555 species (Tab. 7). These monographic treatments cover families and genera for which $\mathrm{c}$. 831 species are now reported from Brazil. Although some of these species will have been described as new or reported for Brazil after the publication of the monograph, for the vast majority of the 831 Brazilian species in these groups a high quality description will be available, either in the monograph or in subsequent papers, often by members of the same research team (e.g. Knapp et al. 2015).

The range of Brazilian Floras cited as supporting references in the Brazilian List ranges from the classic Flora Brasiliensis (Martius et al. 1833; Urban 1906) to Floras at state and local level which were prepared over the course of the 20th Century and continue to be produced to the present day. The results of our partial evaluation of Floras for three Brazilian states and for the Distrito Federal are summarised below.

Flora Ilustrada Catarinense (Illustrated Flora of Santa Catarina)

Initiated and edited by Raulino Reitz and subsequently Ademir Reis (Reitz 1965-1989; Reis 1996-2005), this work comprises 142 fascicles, each treating a single family (or part of a larger family) with the most recent being published in 2005. Of the 132 angiosperm families treated, eight are represented only by species in cultivation. Ten families of pteridophytes s.l. have been published. A total of 4,228 species have been treated, of which 3915 are native species of angiosperm (Reitz 19651989; Reis 1996-2005). The Flora of Santa Catarina is the most complete Flora for a Brazilian State, the number of species treated to date being equivalent to c. $82 \%$ of the angiosperm species recorded for Santa Catarina (BFG 2015). In Santa Catarina the predominant vegetation formations are Dense Ombrophilous Forest, Araucaria Forest and Campos.

Flora Fanerogâmica de São Paulo (Phanerogamic Flora of São Paulo)

Initiated in 2001, this state Flora comprises seven volumes to date, with the most recent having been published in 2012. In total, 151 families have been treated, of which two are gymnosperm families. A total of 3,237 species have been published (Wanderley et al. 2011), equivalent to c. $43 \%$ of the number of angiosperm species reported for São Paulo (BFG 2015). The vegetation of the State of São Paulo is quite diverse, with the dominant vegetation formations being Dense Ombrophilous Forest, Deciduous or Semi-deciduous Forest, High Altitude Grassland and Cerrado (Wanderley et al. 2011).

\section{Flora do Distrito Federal}

The Flora of the Distrito Federal was also initiated in 2001 (Cavalcanti \& Ramos 2001) with the most recent volume having been published in 2013. To date, this work has treated 88 plant families: 70 Seed Plant families and 18 Pteridophyte families and a total of 974 species, of which 860 are Seed Plants (Andrielli C. A. Lopes pers. comm.). This coverage equates to c. $27 \%$ of Seed Plants reported for Distrito Federal (BFG 2015) The vegetation of the Distrito Federal is predominantly Cerrado s.l. (Cavalcanti \& Ramos 2001).

\section{Flora de Sergipe}

This state Flora was initiated in 2013 and, to date, has published one volume treating 37 angiosperm families in which 494 species are reported and described (Prata et al. 2013), equivalent to c. $31 \%$ of those reported for Sergipe (BFG 2015). The most prevalent vegetation types in Sergipe are Humid Forest, Atlantic Forest and Caatinga (Prata et al. 2013). 
Table 3 - Estimated numbers of Brazilian specimens deposited in Brazil and in major herbaria in Europe and the United States.

\begin{tabular}{|c|c|c|}
\hline Brazilian Herbaria (fide IH) & $6,697,300$ & \\
\hline Additions to RB since last update to IH* & 130,000 & \\
\hline Total for Brazilian herbaria & & $6,827,300$ \\
\hline \multicolumn{3}{|l|}{ Major European Herbaria } \\
\hline NHM London (BM) & 300,000 & \\
\hline RBG Kew (K) & 300,000 & \\
\hline MNHN Paris (P) & 420,000 & \\
\hline Munich (M) & 70,000 & \\
\hline Other German herbaria & 60,000 & \\
\hline Montpellier (MPU) & 50,000 & \\
\hline Brussels (BR) & 110,000 & \\
\hline Total for European Herbaria & & $1,310,000$ \\
\hline \multicolumn{3}{|l|}{ Major USA herbaria } \\
\hline New York Botanical Garden (NYBG) & 650,000 & \\
\hline Missouri Botanical Garden (MO) & 208,097 & \\
\hline Smithsonian Institution (US) & 200,000 & \\
\hline Total for USA Herbaria & & $1,058,097$ \\
\hline Grand Total & & $9,195,397$ \\
\hline Area of Brazil in sq km & & $8,514,877$ \\
\hline Specimens per sq $\mathrm{km}$ & & 1.08 \\
\hline
\end{tabular}

* Forzza pers comm.

Table 4 - Comparison of sampling sufficiency estimates for Brazil with those of other tropical Flora projects in progress.

\begin{tabular}{lcccl}
\hline & Area $\left(\mathbf{k m}^{\mathbf{2}}\right)$ & $\begin{array}{c}\text { Specimen } \\
\text { numbers }\end{array}$ & $\begin{array}{c}\text { 'Collection Density' } \\
\text { (Specimens/km²) }\end{array}$ & Source of specimen numbers \\
\hline Earth & $149,000,000$ & $350,000,000$ & 2.35 & Thiers (continuously updated, consulted May 2015) \\
Brazil & $8,514,877$ & $9,195,397$ & 1.08 & This paper \\
Cameroon & 427,710 & 350,000 & 0.82 & G. Gosline pers. comm. \\
Thailand & 515,000 & 494,200 & 0.96 & Thiers (continuously updated, consulted May 2015) \\
\hline
\end{tabular}

Table 5 - Scale and distribution of taxonomic capacity relevant to Brazil.

\begin{tabular}{lccc}
\hline Description of taxonomic activity & Based in Brazil & Based elsewhere & Total \\
\hline Brazilian List Collaborators* & 355 & 58 & 413 \\
Authors of new species with types from Brazil $1990-2006^{* *}$ & 209 & 274 & 483 \\
\hline
\end{tabular}

* Thomas et al. 2012

** Sobral \& Stehmann 2009 
Flora of Brazil OnLine 2020

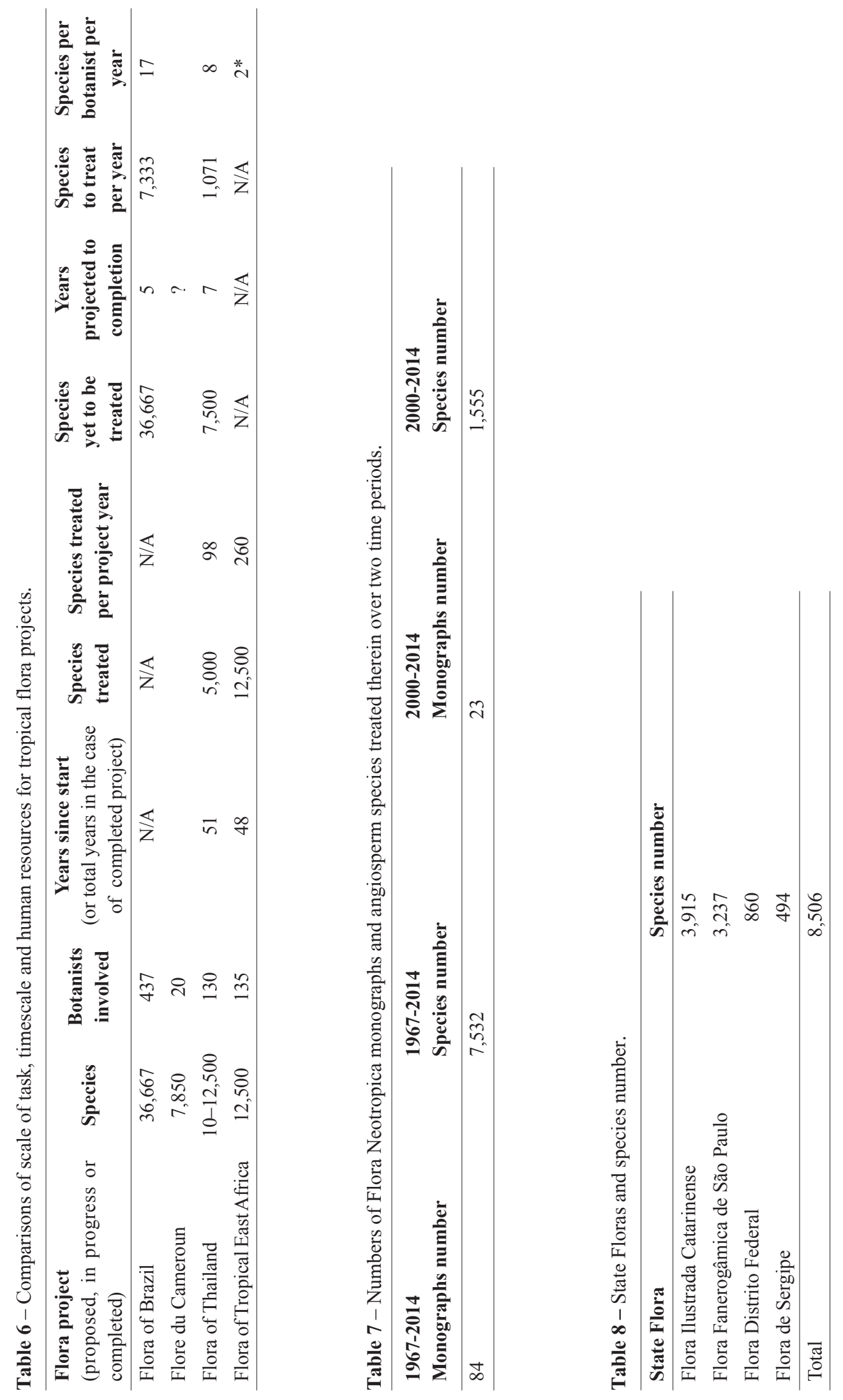


Growth in publication of new species by Brazilbased authors

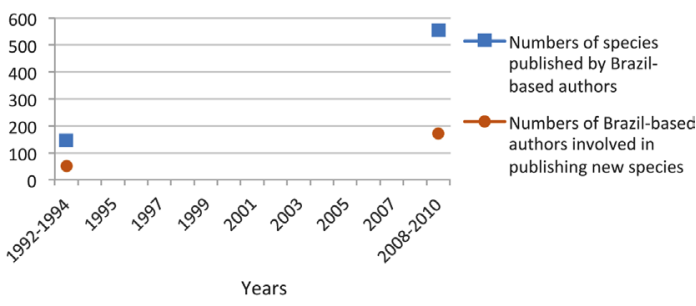

Figure 2-Growth in publication of new species by Brazilbased authors. (Based on data from Cowling et al. in prep.).

Collectively, the four Floras analysed include c. 8,506 species treatments (Tab. 8), a total equivalent to c. $33.5 \%$ of the angiosperm and gymnosperms species reported for Brazil (BFG 2015). It must be borne in mind however that this figure does not represent 8,506 different species, since a significant number of these species are not confined to a single state and thus may have been treated in more than one Flora. Our pairwise comparisons for selected families showed that the extent of overlap in species between Floras varied widely, with unique species as a proportion of total species treatments ranging from 0.95 for Myrtaceae in Santa Catarina and Sergipe to 0.68 for Poaceae in Santa Catarina and São Paulo. Apocynaceae yielded an intermediate value of 0.72 for Santa Catarina and São Paulo. To extrapolate directly from these results would overstate the degree of overlap in species between these Flora treatments since the pairwise comparisons could only be made between families which had been treated for two Floras. For example there are c. 42 families which have been treated for the Flora of Santa Catarina but not yet for the Flora of São Paulo and collectively these account for 2,056 species. For purposes of estimation we assumed that these 2,056 species were not treated elsewhere and that all the other species treatments in state Floras had levels of overlap equivalent to those reported here for Apocynaceae, so that 6,450 species treatments might represent 4,644 different species. Summing these Flora totals $(2,056+4,644)$ with those reported above for monographs $(2,282$ species $)$ gives a total of 8,982 species (Tab.9). Therefore, for at least $28 \%$ of angiosperms and gymnosperms $(8,982$ of the 32,109 species native to Brazil) modern descriptions are available which might form the basis for an online Flora treatment.
Table 9 - Taxonomic treatments and species number.

\begin{tabular}{ll}
\hline Treatments of species & Species number \\
\hline Taxonomic revisions & 2,282 \\
Brazilian Floras & 6,700 \\
\hline Total & 8,982 \\
\hline & \\
Angiosperms and Gymnosperms & 32,109 \\
(BFG 2015) & \\
\% Treated species & $28 \%$ \\
\hline
\end{tabular}

\section{Discussion}

Proportion of flora already known

Our results suggest that as many as $88 \%$ of all Brazilian angiosperm species may already have been discovered and described. This figure is much higher than estimated for the neotropics as a whole (Thomas 2005) but broadly consistent with global level analyses (Joppa et al. $2011 \mathrm{a}, \mathrm{b}$ ) which is scarcely surprising, since it is derived from the same model applied in a Brazilian context (Pimm et al. 2010). The credibility of this result depends to a large extent on whether the assumptions inherent in the model and analyses are valid in a Brazilian context. Hence, we evaluate the assumptions underlying the original analyses and the extrapolation presented above before attempting to discuss the broader significance of the result.

Apart from rates of description of species over time, the two key factors involved in the model presented by Joppa et al. (2011a) are (i) taxonomic effort, defined as the number of taxonomists involved in describing species, and (ii) taxonomic efficiency, defined as the number of species described per taxonomist adjusted for the continually diminishing pool of unknown species. The logic underpinning the model is that taxonomic effort is a powerful predictor of the number of species described and if numbers of species described per individual scientist involved in species description are declining over time, that decline must be attributable to a shrinking pool of species yet to be discovered/described. Joppa et al. (2011a) found that at global level, for many plant taxa there was an increase in taxonomic efficiency over the course of a century or more, followed by a decline which they attributed to the declining pool of species as-yet-unknown. In a Brazilian context, 
Pimm et al. (2010) considered species endemic to each region of Brazil and reported similar patterns of increase then decrease in taxonomic efficiency, with the shape of the curve differing from region to region, resulting in widely varying predictions of proportions of plant species yet to be described from each region (from $9 \%$ in Southeast Brazil to $49 \%$ in Northeast Brazil).

To what extent are these model assumptions defensible in light of the data available today? The results reported under Taxonomic Capacity above are certainly compatible with the assumption that, in broad terms, taxonomic effort is a powerful predictor of number of species described, with a four-fold increase in species described associated with a $>$ three-fold increase in botanists involved. However, the data do not provide support for the idea of a decline in taxonomic efficiency, rather this limited dataset is suggestive of increased taxonomic efficiency when the later period studied is compared to the earlier, an anomaly which has prompted a more detailed treatment elsewhere (Nic Lughadha, Morim in prep.).

Beyond the assumptions built into the Pimm et al. (2010) model, it is important to consider assumptions implicit in the selection of the datasets to which the model is applied. For both global and Brazilian analyses, the dataset comprised species lists for all monocots and selected non-monocot families (sourced from the World Checklist of Selected Plant Families). Thus monocots were over-represented, accounting for $58 \%$ of all the species in the global analysis although only one in five angiosperms are monocots (R. Govaerts, pers. comm. 2015). Exact figures were not supplied for the Brazilian analysis but since c. $27 \%$ of Brazilian angiosperms are monocots (Forzza et al. 2010) and all known monocots were included in the list from which the sample was drawn they were certainly over-represented among the 6,382 angiosperm species analysed by Pimm et al. 2010 (Tab. 1). There was an implicit assumption in both global and Brazilian studies that, despite being dominated by monocots, the datasets analysed were broadly representative of angiosperm diversity at global and national level respectively. This latter assumption is arguably the most important, since the inferences to be drawn from our extrapolation depend directly on it. A robust test of the validity of extrapolating from the monocot-dominated dataset to angiosperms more broadly is beyond the scope of this review and the fact that Brazilian monocot species have slightly higher levels of endemism than Brazilian angiosperms as a whole ( $60 \%$ vs $57 \%$, fide Forzza et al. 2010) might be considered cause for concern. However, the strong correlations we found between numbers of endemic species analysed by Pimm et al. (2010) and numbers of Apocynaceae and angiosperms respectively endemic to these regions lend some support to the idea that patterns of species richness may be similar.

In summary, although not all model assumptions can be fully explored, most appear credible enough to suggest that our results extrapolated from the Pimm et al. (2010) modelled results merit consideration. What are the implications of these results for the preparation of a Flora of Brazil? Our overall estimate that c. $88 \%$ of Brazilian species have already been discovered and described is encouraging, as is the result that almost half the of the predicted additions are likely to be already known from other countries suggesting that those undertaking treatments of particular groups for the Flora will not be overwhelmed by an endless stream of novelties to be described as new to science. However, the simple fact that the great majority of Brazilian plant species are already known to science should not lead us to underestimate the work involved in treating them effectively in an online Flora, including, among others, documenting their morphological variation throughout their known range, addressing gaps in knowledge of their distribution (e.g. through new collections) and their circumscription (e.g. through phylogenetic and phylogeographic studies). Our indicative results on the regional distribution of species new to science are arguably more useful for those planning the Flora: they suggest that of the 2,618 species yet to be discovered and described as new to science, close to half $(1,194=46 \%)$ are confined to Northeast Brazil. Conversely, we can predict that most of the projected 1,963 additions to the Flora of species already known from other countries will not be found in Northeast Brazil but in regions bordering other South American countries. For example, in their analysis of five years of additions to the flora of Acre, Medeiros et al. (2014) reported 34 additions to the flora of Brazil of which most $(23=67 \%)$ had previously been described from other countries, while just $11(33 \%)$ were new to science (including some species still awaiting publication). 
Sampling sufficiency

Comparing our 2015 estimate of 6.7 million specimens reported by Index Herbariorum as deposited in Brazilian herbaria to equivalent figures of 3 million and 4.9 million for 1990 and 2006 respectively (Sobral \& Stehmann 2009), indicates significant growth over the past 25 years in numbers of specimens deposited in Brazilian herbaria (Fig 1). The data also suggest an acceleration in growth rate in the past decade compared to the previous 15 years. However, since the intervals at which herbaria provide updates to Index Herbariorum on their accession numbers are variable and often long, caution must be exercised in interpreting the data in terms of trends over time. Combining our collation of published information for Brazilian herbarium holdings with estimates from curators of herbaria outside Brazil which hold important collections of Brazilian material yielded an estimate of 9.2 million specimens. We consider this estimate to be conservative for several reasons: (i) delayed reporting of Brazilian herbarium holdings to Index Herbariorum (as illustrated under Results); (ii) we approached only a very limited selection of the non-Brazilian herbaria with important deposits of material collected in Brazil, so holdings outside Brazil are certainly underrepresented in our sample. Balancing these factors tending to under-estimation is the fact that the figures supplied (i) include non-Brazilian material deposited in Brazilian herbaria, (as outlined under Results) and (ii) are generally not confined to angiosperm holdings but may include other groups including non-vascular plants, algae and fungi. While specimens other than of vascular plants are in a minority in most herbaria they represent an important proportion in some cases (e.g. NY) or even the majority of the collection in several instances (e.g. URM at the Federal University of Pernambuco specialises in tropical and temperate fungi and lichens) so that a total restricted to angiosperms might sum to $<8$ million specimens.

Our estimates suggest that numbers of specimens exceed the arbitrary threshold value of 100 herbarium specimens per $100 \mathrm{~km}^{2}$ suggested by Campbell (1989) as being the "minimum necessary to ensure that a botanical inventory has sampled most of the taxa and gathered sufficient distributional information'. Applying this criterion, Brazil considered as a whole would be deemed to have reached sampling sufficiency, a situation which was not envisaged by Campbell (1989) who, based on reported increase in collections over the period 1974-81, projected a 51 year interval before Brazil would reach such collection densities. Collecting densities in Brazil are now broadly comparable to or slightly in excess of those estimated for Cameroon and Thailand, where Flora projects are ongoing.

Shepherd (2003) deemed Campbell's arbitrary threshold conservative and suggested that three collections per $\mathrm{km}^{2}$ would be more appropriate. While many tropical botanists (including the present authors) might agree with Shepherd in principle, it would be unrealistic in practice to refrain from embarking on a Flora project until this ambitious target was met, as our results suggest that it has not yet been met for most parts of the world, given our calculated global mean of 2.4 specimens per $\mathrm{km}^{2}$. In fact, the global mean is not very meaningful as it masks the extreme disparities between the extraordinarily high collection densities in many temperate areas and the many areas of the world which would still be considered 'poorly collected'in Campbell's terms (see below for definition). The same can be said for Brazil, given the vast extent of the territory to be considered and the distributions of herbaria and of collecting effort, both strongly skewed to the South and Southeast regions. Our results indicate that despite an apparent increase in the rate of growth of the collections, coupled with increased awareness of the need for additional collections in the North and Northeast (e.g. Sobral and Stehmann 2009; Medeiros et al. 2014; Moro et al. 2014) there has been little or no change in the proportions of the collections deposited in the major regions of Brazil over the past decade or more (Tab. 2).

Values at regional level are perhaps the most relevant for addressing the question as to whether collection densities are sufficient to support the development of a Flora, though they need to be interpreted carefully in light of the fact that they only represent material deposited in Brazil. At this scale the contrast between the South and Southeast and the remainder of Brazil is stark. Collection densities for the South are far in excess of Campbell's (1989) threshold and equal the global mean of 2.4 specimens per $\mathrm{km}^{2}$. Herbaria in the Southeast hold c. $47 \%$ of all the herbarium specimens deposited in Brazil and include greater numbers of specimens collected from other regions of Brazil than is the case for herbaria based in other regions. Therefore the calculated collection density of 3.4 specimens per $\mathrm{km}^{2}$ probably over- 
represents the level of sampling for the Southeast. Nonetheless, there can be no doubt that sampling in the South and Southeast is sufficient to support production of state Floras, since significant progress has been made in the publication of Floras of São Paulo and Santa Catarina, as described earlier in this review.

For the remainder of Brazil, Shepherd's threshold of 3 specimens per $\mathrm{km}^{2}$ is far above the reality and our discussion is probably best framed in terms of the additional criteria proposed by Campbell (1989) who introduced the terms 'relatively well-collected' for areas with more than 50 specimens per $100 \mathrm{~km}^{2}$ and 'poorly collected' for those with fewer than 50 specimens per $100 \mathrm{~km}^{2}$. Thus the Centre-West and North regions, which have collection densities of 0.4 and 0.2 specimens per $\mathrm{km}^{2}$ respectively, judged only on collections deposited within their own region, would qualify as 'poorly collected' in Campbell's terms. When collections deposited outside the region are considered, the Centre-West would likely qualify as relatively wellcollected. In contrast, even allowing for the major holdings from this region deposited in other regions of Brazil (e.g. $>60,000$ at RB), and overseas (e.g c. 60,000 at $\mathrm{K}$ and $>80,000$ at NY) the North is barely halfway to the threshold for being deemed 'relatively well-collected'. The historical, economic and sociological factors underpinning this sampling deficit are discussed in detail by Sobral \& Stehmann (2009), as are some of the implications in terms of basic understanding of Amazonian plant diversity and its conservation status.

While there are compelling arguments for increased investment in documenting the Amazon flora the immediate question to be addressed is: should the sampling deficit be considered so severe as to render attempts at a Flora unviable? We think not. Utility must be the primary consideration in evaluating whether a project is worthwhile. A Flora that facilitated identification of the great majority of the species most likely to be encountered in the Brazilian Amazon would surely be recognised as an important and useful contribution, even if many rarer species received only tentative or provisional treatments. Recent insights into the distribution of Amazon tree diversity has shown that just 5,000 tree species account for $>99 \%$ of the trees in the Amazon forests as a whole (ter Steege et al. 2013). A Flora that treated these in some detail, complemented by preliminary treatments for other species less frequently encountered, would provide a very useful foundation which could be improved over time. In fact, this pragmatic approach highlights an important difference between Flora projects initiated in the $21^{\text {st }}$ Century and those with longer histories. The discussions in the literature as to levels of collection density which are sufficient to support a Flora date, for the most part, from a time when hard copy publication was the norm, with Floras being published in fascicles as families were completed or in large volumes encompassing several families (e.g. Prance 1977). The primary disadvantage of publishing a Flora treatment based on insufficient collections was that the publication would soon be rendered out of date by the discovery of new species and range extensions for known species, necessitating the production of supplements or second editions at significant cost in time and money. In contrast, the online approach adopted in the development of the Flora of Brazil renders low collection densities a much less troubling problem. As new collections become available, revealing new distributions or even new species, the family treatments can be updated with the latest information.

The collection density of 0.6 per $\mathrm{km}^{2}$ estimated for NE Brazil indicates that it qualifies as 'relatively well collected' in Campbell's terms. At first glance, this finding may appear surprising in light of results presented earlier (Pimm et al. 2010 and this paper) suggesting that the number of endemic species yet to be discovered/described from NE Brazil is similar to the number already known. However, the two conclusions are not necessarily contradictory. Even relatively high overall collection densities can result in poor representation of the flora when the distribution of collections is very uneven, as is the case for NE Brazil. The effects of uneven collection may be amplified by the fact many NE Brazilian species may have more restricted distributions than species of the cerrado, for example (Moro et al. 2014).

We found no evidence to suggest that inadequate sampling sufficiency would provide such a severe impediment that it would be inadvisable to initiate a national Flora at this stage. However, it is important to note that while Campbell's approach and threshold values provide a useful starting point for discussion and for comparison between countries they are very much a product of their time and a more sophisticated and multi-faceted consideration of the availability of specimens for the production of a Flora will 
likely prove more useful going forward. Two aspects of Campbell's metric appear to have been driven by pragmatism rather than best practice. Firstly, he considered specimens (typically single sheets), rather than collections which typically comprise multiple sheets prepared from single gathering bearing the same collector number, which are later separated and distributed to different herbaria, so that the number of sheets deposited in herbaria may exceed the number of collections made by five-fold or more. Secondly, Campbell considered only those sheets deposited in-country because these were the data readily available via Index Herbariorum. Sobral \& Stehmann (2009) followed the same approach for similar reasons, reporting that numbers of specimens of Brazilian plants in foreign herbaria were difficult to evaluate. The advent of the Reflora Programme, and its current focus on digital repatriation of Brazilian herbarium specimens has resulted in rapid change in this landscape, as scientists in major European and US herbaria prepared estimates of the size of their Brazilian holdings in preparation for their digitisation. Thus, estimating numbers of sheets of Brazilian collections deposited outside Brazil is a much easier task in 2015 than in 2008. Once these specimen data are digitised and accessible via a single interface, true estimates of collection densities (as distinct from specimen densities) should be achievable. These estimates, combined with the tools now available within Lacunas (Canhos et al. 2013) to evaluate numbers of collections per species, will provide much more meaningful and refined insights into the areas and the taxa for which lack of collections represents a major impediment to the production of the Flora of Brazil.

\section{Taxonomic capacity}

Is there sufficient botanical expertise available to develop such a big project over a five-year period?

Our results showed that the annual rate of production of species treatments required to complete a Brazilian flora by 2020 was ambitious, when compared to tropical Flora projects which were ongoing or recently completed, but that the taxonomic capacity recently engaged on the enhancement of the Brazilian List which could potentially be mobilised for future work, was proportionate to the scale of the challenge. In other words, the relevant expertise clearly exists in sufficient quantity, 437 collaborators fide BFG (2015), but there remains a question as to whether it can be mobilised and focused sufficiently on the delivery of the Flora. Twenty or even ten years ago, few taxonomists might have declined the opportunity to make a substantial contribution to a Flora of this importance. It remains to be seen whether this is still the case, despite increasing focus by agencies co-ordinating scientific research and higher education on metrics based on impact factor of journal publications, citations, and grantfunding secured. The fact is that many of those who have the knowledge and experience to produce authoritative, high-quality taxonomic treatments for the Flora at the pace and scale required to meet the 2020 Target may also be considering the potential impact of this commitment on their career prospects. The ageing profile of the taxonomic specialists willing to tackle large groups has been noted by Medeiros et al. (2014) who also reported a shortage of younger taxonomists willing to take their places. Increased availability of data in digital form coupled with user-friendly interfaces to streamline the preparation of species treatments may lighten the burden of the task for taxonomists but it may prove equally important to ensure that the importance of their contributions to science and conservation in Brazil are recognised at the highest level and that this recognition is incorporated into the systems and metrics by which scientists are evaluated and rewarded.

\section{Building on existing treatments}

The numbers of species treatments reported in our (partial) survey of taxonomic revisions, State Floras and Distrito Federal Flora and the proportion of Brazilian angiosperm species which we estimate that they encompass (28\% Tab.9) might not, in principle, seem very encouraging, since they immediately prompt further questions, perhaps the most important being: "Are there taxonomic treatments available for the remainder (the majority) of the angiosperm species known from Brazil, other than in their original place of publication?'

Although we do not have a complete survey of all taxonomic treatments, with totals for different species treated therein, our review of the data for the period 2000-2015 in the Bibliographic Reference field of the Brazilian List provides a qualitative overview of the taxonomic treatments available for the angiosperm flora of Brazil. Beyond the classic 
$19^{\text {th }}$ Century works, various taxonomic revisions were produced during the $20^{\text {th }}$ Century, both by Brazilian botanists and others. Despite changes in nomenclature and taxonomic circumscription in the interim, as well as the addition of newly described species, works such as those compiled for Orchidaceae (Pabst \& Dungs 1977) or for the genus Mimosa (Barneby 1991) represent invaluable syntheses of information on the morphology of species which will be important resources for the preparation of Flora do Brasil 2020. There are also many important treatments of groups above the level of species focused on a particular ecosystem or politically-defined area which have not been incorporated into a formal state Flora (e.g. AlvesAraújo et al. 2009; Barros \& Morim 2014; Esteves 2001; Queiroz 2009; Soares et al. 2014). Such treatments were not sampled quantitatively in this review, though there are many (BFG 2015). Thus our estimate of the numbers of relevant species treatments available is very conservative.

We have emphasized the importance of existing taxonomic treatments for the Brazilian List but of course, such benefits accrue in the other direction also: the Brazilian List has played an important role in the updating of taxonomic revisions. Knapp et al. (2015) comments that following the revision of the Solanum havanense species group (section Geminata (G. Don), in which 35 species were reported for Brazil, nomenclatural updates and information made available about the Geminata clade of Solanum in the Brazilian List gave rise to the recognition of a further nine species records for Brazil, as well as updating the information on the diversity and distribution of species of this clade.

Beyond the Flora Neotropica series and the four Brazilian Floras included in our results, there is a considerable number of studies focused on local Floras, some with a focus on Protected Areas. In general, neither state Floras nor local Floras have a regular publication schedule and many remain unfinished. Nonetheless, as for the other sources cited, they provide collated information on Brazilian species, at more restricted geographical scales. For regions such as the Amazon, these Floras are all the more important because they provide some of the few contemporary sources on the flora of the region. The series of articles concerning Flora of the Reserva Ducke (Manaus, Amazonas) represent a good example of this kind. This series made its mark with the treatment of 165 taxa (pteridophytes and angiosperms) published in Rodriguesia (Freitas \& Forzza 2005 in editorial). Existing knowledge which documents the morphological variation of the Brazilian species and their adpatations to the widely differing environmental conditions in the areas where they occur can be evaluated qualitatively across the broad spectrum of taxonomic treatments (revisions and Floras) already available for the Brazilian flora. Thus we concur with the conclusions of Thomas et al. (2012) in which, among other information sources mentioned by the authors, small-scale Floras are recognised as the basis for the preparation of more wide-ranging Floras, and monographs which treat all the species of a single group can be as important as partial treatments and regional revisions.

Summarising, our review suggests that while levels of taxonomic coverage, collection densities and availability of taxonomic capacity may not yet have reached optimal levels in Brazil they need not represent insurmountable barriers to the creation of an Online Flora of Brazil by 2020. The proportion of the Flora which is already known, estimated here at $88 \%$, is such that new discoveries will be the exception rather than the rule in most regions. Overall collection densities have improved significantly and compare favourably to those for other tropical countries with Floras in preparation, though the long-standing problem of undersampling in the North continues, and more intensive collection in the Northeast may also be required in order to detect the many undescribed species likely to occur there. Recent species descriptions exist for many of the species to be treated for the Flora, and will often serve as a useful starting point, although they vary greatly in scope, level of detail and degree of accessibility. And, perhaps most importantly, the trained taxonomic workforce of scientists who have already demonstrated significant commitment to enhancing the Brazilian List represents a key asset, which, if harnessed effectively, has the potential to deliver another outstanding success in the form of a comprehensive online resource covering the most species-rich flora in the world.

\section{Conclusions}

From the classic works produced in the $19^{\text {th }}$ Century to the present, a rich and diverse knowledge base on the species of the Brazilian flora is available in a variety of forms and scopes in taxonomic treatments (revisions and Flora), 
most notably the national Flora completed in the early years of the twentieth century (Martius et al.1833; Urban 1906). The taxonomic identities of the 32,086 angiosperm species then known to occur in the country, along with a suite of detailed information about each species, were compiled and checked by a network of 437 specialists over the past seven years, as part of the different stages in the finalisation of the Brazilian List . This synthesis has in turn provided a basis for a series of novel analyses of the diversity of plants and fungi of Brazil (BFG 2015; Costa \& Peralta 2015; Maia et al. 2015; Menezes et al. 2015; Prado et al. 2015).

The body of knowledge of Brazilian plants generated over the decades of taxonomic endeavour in Brazil is intimately linked to and, in large part, based on the enormous number of specimens deposited in herbaria within Brazil and in other countries, which day-by-day are being digitised and made available online, in the form of Virtual Herbaria. Initiatives such as the Reflora Virtual Herbarium illustrate the progress which has been made. To date more than one million high resolution images of specimens from different herbaria, in Brazil and elsewhere, are available not only for reference purposes but also so that taxonomists can add new determinations, nomenclatural updates and information of other kinds, where appropriate.

In this context, we consider that planning an online Flora of Brazil for 2020 is a realistic idea, based on a solid foundation. Our awareness of the limitations and lacunas in our knowledge of the flora should not deter us from our efforts to document it. On the contrary, this awareness should form the basis for a strategic plan that envisages proceeding with the Flora, while at the same time directing efforts and resources to build taxonomic capacity and address the numerous knowledge gaps. Furthermore, it must always be borne in mind that the preparation of an Online Flora allows for continuous updating, as our knowledge of the flora improves. This incremental approach has had notable success over the past seven years. Indeed, the present moment seems to offer a unique opportunity to capture the momentum created by the finalisation of the Brazilian List and the major milestones reached by Reflora, building on these achievements to reach the new, still more challenging target.

To meet Target 1 of the GSPC by 2020 is, without doubt, a huge project which will require consideration of aspects beyond the capacity and motivation of the taxonomic community: interinstitutional linkages, financial investment and the support of decision-makers will be fundamental to the success of the project. Providing the conditions and resources required for the development of the Flora of Brazil Online 2020 is a responsibility which Brazil, as a party to the CBD, must accept and incorporate as an integral part of government policies and plans.

\section{Acknowledgements}

The authors are grateful to the following, without whom preparation of this review would have been difficult, if not impossible: taxonomists Cassia M.Sakuragui, Rafaela C.Forzza, Thiago E.C. Meneguzzo and Wayt Thomas who shared data on the number of species treated in: Philodendron section Macrobelium, Aechmea subg.Chevalliera, Orchidaceae and in Flora Neotropica Monographs (2010-2014) respectively; Andrielle C. A. Lopes who shared data on the Flora of the Distrito Federal; Lucas S. B. Jordan who collaborated on the quantitative survey of species of Flora Ilustrada Catarinense; Catia Canteiro who assisted in the preparation of the Figures; Martin Cheek and Daniela Zappi who provided useful comments which helped improve an earlier version of the manuscript; two anonymous referees who provided helpful suggestions to improve the final manuscript; Rafael Govaerts, Rafaela Forzza and Luis Alexandre Estevão da Silva who provided prompt responses to last-minute requests for missing facts; Fabiana L. Ranzato Filardi and Paula Leitman who responded patiently to queries throughout the preparation of the "Lista de Espécies da Flora do Brasil" and continue to do so on a daily basis; all taxonomists who work with plants in Brazil.

\section{References}

Alves-Araújo, A; Dutilh, J.H.A. \& Alves, M. 2009. Amaryllidaceae s.s. e Alliaceae s.s. no Nordeste Brasileiro. Rodriguésia 60: 311-331.

Andrade-Lima, D. 1984. A botânica da Carta de Pero Vaz de Caminha. Rodriguésia 36: 5-8.

Antonelli, A. \& Sanmartín, I. 2011. Why are there so many plant species in the Neotropics? Taxon 60 : 403-414.

Barbosa, M.V de \& Peixoto, A. 2003. Coleções botânicas brasileiras: situação atual e perspectivas. In: Peixoto, A. (org.). Coleções biológicas de apoio ao inventário, uso sustentável e conservação de biodiversidade. Instituto de Pesquisas Jardim 
Botânico do Rio de Janeiro, Rio de Janeiro. Pp. 113-125.

Barneby, R.C. 1991. Sensitivae censitae: a description of the genus Mimosa Linnaeus. (Mimosaceae) in the New World. Bronx, N.Y. New York Botanical Garden, New York. 835p.

Barros, M.J.F. \& Morim, M.P. 2014. Senegalia (Leguminosae, Mimosoideae) from the Atlantic Domain, Brazil. Systematic Botany (2014) 39: 452-477.

BFG. 2015. Growing knowledge: an overview of Seed Plant diversity in Brazil. Rodriguésia 66: 1085-1113.

Campbell, D.G. 1989. The importance of floristic inventory in the tropics. In: Campbell, D.G. \& Hammond, D. (eds.). Floristic inventory of tropical countries: the status of plant systematics, collections, and vegetation, plus recommendations for the future. New York Botanical Garden, New York. Pp 5-30.

Canhos, D.L; Sousa-Baena, M.S.; Souza, S.; Garcia, L.C.; Giovanni, R.; De Costa Maia, L. \& Bonacelli M.B.M. 2013. Lacunas: a web interface to identify plant knowledge gaps to support informed decisionmaking. Biodiversity and Conservation 23: 587. DOI: 10.1007/s10531-013-0587-0.

Cavalcanti, T.B. \& Ramos, A.E. 2001. Flora do Distrito Federal Brasil. Vol.1. Embrapa Recursos Genéticos e Biotecnologia, Brasília. 359p.

CDB. 1992. Convention on biological diversity Available at <https://www.cbd.int/doc/legal/cbd-en.pdf $>$. Access on 5 May 2015.

Clark, R.; Wearn, J.; \& Simpson, D.A. (eds.). 2014. Abstracts from 16th Flora of Thailand Conference 2014. Thai Forest Bulletin. Botany 42: 105-152.

Costa, D.P. \& Peralta, D.F. 2015. Bryophytes diversity in Brazil Rodriguésia 66: 1063-1071.

Esteves, G.L. 2001. Pavonia Cav. (Malvaceae) na Região Sudeste do Brasil. Boletim do Instituto de Botânica (São Paulo) 15: 125-194.

Executive Secretary to the Convention on Biological Diversity (2010). Global strategy for plant conservation: technical rationale, justification for updating and suggested milestones and indicators. Avaiable at $<$ https://www.cbd.int/doc/meetings/ cop/cop-10/official/cop-10-19-en.pdf>. Access on 10 May 2015.

Filgueiras, T.S. \& Peixoto, A. L. 2002. Flora e vegetação do Brasil na Carta de Caminha. Acta Botanica Brasilica 16: 263-272.

Forero, E. \& Mori, S. 1999. The organization for Flora Neotropica. Brittonia 47: 379-393.

Forzza, R.C.; Baumgratz, J.F.A.; Bicudo, C.E.M.; Canhos, D.A.L.; Carvalho Jr., A.A.; Costa, A.F.; Costa, D.P.; Hopkins, M.; Leitman, P.M.; Lohmann, L.G.; Maia, L.C.; Martinelli, G.; Menezes, M.; Morim, M.P.; Nadruz-Coelho, M.A.; Peixoto, A.L.; Pirani, J.R.; Prado, J.; Queiroz, L.P.; Souza, V.C.;
Stehmann, J.R.; Sylvestre, L.; Walter, B.M.T. \& Zappi, D.(eds.). 2010. Catálogo de plantas e fungos do Brasil. 2 vols. Andrea Jakobsson Estúdio / Jardim Botânico do Rio de Janeiro, Rio de Janeiro. 1699p.

Forzza, R.C.; Baumgratz, J.F.A.; Bicudo, C.E.M.; Canhos, D.; Carvalho Jr., A.A.; Nadruz-Coelho, M.A.; Costa, A. F.; Costa, D.P.; Hopkins, M.; Leitman, P.M.; Lohmann, L.G.; Lughadha, E.N.; Maia, L.C.; Martinelli, G.; Menezes, M.; Morim, M.P.; Peixoto, A.L.; Pirani, J.R.; Prado, J.; Queiroz, L.P.; Souza, S.; Souza, V.C.; Stehmann, J.R.; Sylvestre,L.S.; Walter, B.M.T. \& Zappi, D.C. 2012. New Brazilian floristic list highlights conservation challenges. BioScience 62: 39-45.

Freitas, L. \& Forzza, R.C. 2005. Flora da Reserva Ducke, Amazonas, Brasil. Rodriguésia 56: Editorial.

Giulietti, A.M. \& Forero, E. 1990. "Workshp" Diversidade taxonômica e padrões de distribuição de angiospermas brasileiras. Acta Botanica Brasilica 4:3-9.

[IBGE] 2015. Instituto Brasileiro de Geografia e Estatística. Available at $<$ http://www.ibge.gov.br $>$. Access on 22 April 2015.

Joppa, L.N.; Roberts, D.L. \& Pimm, S.L. 2011 a. How many species of flowering plants are there. Proceedings of the Royal Society B: Biological Sciences 278: 554-559. DOI:10.1098/rspb

Joppa, L.N.; Roberts, D.L. \& Pimm, S.L. 2011 b. The population ecology and social behaviour of taxonomists. Trends in Ecology and Evolution 26: 551-553.

Knapp, S; Stehmann, J. R. \& Giacomin, L. L. 2015. New species, additions and a key to the Brazilian species of the Geminata clade of Solanum L. (Solanaceae) in Brazil. PhytoKeys 47: 1-48.

Linnaeus, C. 1753. Species Plantarum. Stockholm: Laurentii Salvii apud Forzza, R.C.; Baumgratz, J.F.A.; Bicudo, C.E.M.; Canhos, D.A.L.; Carvalho Jr., A.A.; Costa, A.F.; Costa, D.P.; Hopkins, M.; Leitman, P.M.; Lohmann, L.G.; Maia, L.C.; Martinelli, G.; Menezes, M.; Morim, M.P.; Nadruz-Coelho, M.A.; Peixoto, A.L.; Pirani, J.R.; Prado, J.; Queiroz, L.P.; Souza, V.C.; Stehmann, J.R.; Sylvestre, L.; Walter, B.M.T. \& Zappi, D. (eds.). 2010. Catálogo de plantas e fungos do Brasil. Vol. 1. Andrea Jakobsson Estúdio / Jardim Botânico do Rio de Janeiro, Rio de Janeiro. 22-42.

Lista de espécies da Flora do Brasil. 2015. Available at $<$ http://floradobrasil.jbrj.gov.br/>. Access on 28 May 2015.

Longhi-Wagner, H.M.; Bittrich, V.; Wanderley, M.G.L. \& Shepherd, G.J. 2001. Poaceae. In: M.G.L. Wanderley, G.J. Shepherd \& A.M. Giulietti (coords.). Flora Fanerogâmica do Estado de São Paulo. Vol. 1. Fapesp \& Hucitec, São Paulo. 291p.

Maia, L.C.; Carvalho Júnior, A.A.; Cavalcanti, L.H.; Gugliotta, A.M.; Drechsler-Santos, E.R.; Santiago, 
A.L.M.A.; Cáceres, M.E.S.; Gibertoni, T.B.; Aptroot, A.; Giachini, A.J.; Soares, A.M.S.; Silva, A.C.G.; Magnago, A.C.; Goto, B.T.; Lira, C.R.S.; Montoya, C.A.S.; Pires-Zottarelli, C.L.A.; Silva, D.K.A.; Soares, D.J.; Rezende, D.H.C.; Luz, E.D.M.N.; Gumboski, E.L.; Wartchow, F.; Karstedt, F.; Freire, F.M.; Coutinho, F.P.; Melo, G.S.N.; Sotão, H.M.P.; Baseia, I.G.; Pereira, J.; Oliveira, J.J.S.; Souza, J.F.; Bezerra, J.L.; Araujo Neta, L.S.; Pfenning, L.H.; Gusmão, L.F.P.; Neves, M.A.; Capelari, M.; Jaeger, M.C.W.; Pulgarín, M.P.; Menolli Junior, N.; Medeiros, P.S.; Friedrich, R.C.S.; Chikowski, R.S.; Pires, R.M.; Melo, R.F.; Silveira, R.M.B.; Urrea-Valencia, S.; Cortez, V.G. \& Silva, V.F. 2015. Diversity of Brazilian Fungi. Rodriguésia 66: 1033-1045.

Martius, C.E.P.; Escheweiler, G.G. \& Nee ab Esenbeck, C.G.1833. Flora Brasiliensis par, prior. Sumptibus J.G. Cottae Stuttigartiae et Tubingen. Pp 1-50.

Medeiros, H.; Obermüller, F.A.; Daly, D.C.; Silveira, M.; Castro, W. \& Forzza, R.C. 2014. Botanical advances in Southwestern Amazonia: The flora of Acre (Brazil) five years after the first Catalogue. Phytotaxa 177: 101-117.

Menezes, M.; Bicudo, C.E.M.; Moura, C.W.N.; Alves, A.M.; Santos, A.A.; Pedrini, A.G.; Araújo, A.; Tucci, A.; Fajar, A.; Malone, C.; Kano, C.H.; Sant'Anna, C.L.; Branco, C.Z.; Odebrecht, C.; Peres, C.K.; Neuhaus, E.B.; Eskinazi-Leça, E.; Aquino, E.; Nauer, F.; Santos, G.N.; Amado Filho, G.M.; Lyra, G.M.; Borges, G.C.P.; Costa, I.O.; Nogueira, I.S.; Oliveira, I.B.; Paula, J.C.; Nunes, J.M.C.; Lima, J.C.; Santos, K.R.S.; Ferreira, L.C.; Gestinari, L.M.S.; Cardoso, L.S.; Figueiredo, M.A.O.; Silva, M.H.; Barreto, M.B.B.B.; Henriques, M.C.O.; Cunha, M.G.G.S.; Bandeira-Pedrosa, M.E.; Oliveira-Carvalho, M.F.; Széchy, M.T.M.; Azevedo, M.T.P.; Oliveira, M.C.; Cabezudo, M.M.; Santiago, M.F.; Bergesh, M.; Fujii, M.T.; Bueno, N.C.; Necchi Jr., O.; Jesus, P.B.; Bahia, R.G.; Khader, S.; Alves-da-Silva, S.M.; Guimarães, S.M.P.B.; Pereira, S.M.B.; Caires, T.A.; Meurer, T.; Cassano, V.; Werner, V.R.; Gama Jr., W.A. \& da Silva, W.J. Update of the Brazilian floristic list of Algae and Cyanobacteria. Rodriguésia 66: 1047-1062.

Mittermeier, R.A.; Myers, N.; Thomsen, J.B.; Fonseca, G.A.B. \& Olivieri, S. 1998. Biodiversity hotspots and major tropical wilderness areas: approaches to setting conservation priorities. Conservation Biology 12: 516-520.

Moro, M.F.; Nic Lughadha, E.; Filer, D.L.; Araujo, F.S. de \& Martins, F.R. 2014. A Catalogue of the vascular plants of the Caatinga phytogeographical domain: a synthesis of floristic and phytosociological surveys. Phytotaxa 160:1-118.

Murray-Smith, C.; Brummitt, N.A.; Oliveira-Filho, A.T.; Bachman, S.; Moat, J.; Nic Lughadha, E.M. \& Lucas E.J. 2009. Plant diversity hotspots in the atlantic coastal forests of Brazil. Conservation Biology 23: 151-163.

Myers, N.; Mittermeier, R.A.; Mittermeier, C.G.; da Fonseca, G.A.B. \& Kent, J. 2000. Biodiversity hotpots for conservation priorities. Nature 403: 853-858.

Nic Lughadha, E.M. 2004. Towards a working list of all known plant species. Philosophical Transactions of the Royal Society B-Biological Sciences 359: 681-687.

Organization for Flora Neotropica Monograph 19672007. Monograph $\mathrm{n}^{\circ} 1-100$. The New York Botanical Garden, New York.

Pabst, G.F.J. \& Dungs, F. 1977. Orchidaceae Brasilienses. Vol. 2. Brücke-Verlag Schmersow, Hildescheim. $418 \mathrm{p}$.

Paton, A. \& Nic Lughadha, E. 2011. The irresistible target meets the unachievable objective: what have 8 years of GSPC implementation taught us about target-setting and achievable objectives? Botanical Journal of the Linnean Society 166: 250-260.

Peixoto, A.L. 1999. Brazilian botany on the threshold of the $21^{\text {th }}$ century: looking throughthe scientific collections. Ciência e Cultura 51: 349-362.

Pimm, S.L.; Clinton, N.J.; Joppa, L.N.; Roberts, D.L. \& Russell, G.J. 2010. How many endangered species remain to be discovered in Brazil? Natureza e Conservação 8: 71-77.

Prado, J.; Sylvestre, L.S.; Labiak, P.H.; Windisch, P.G.; Salino, A.; Barros, I.C.L.; Hirai, R.Y.; Almeida, T.E.; Santiago, A.C.P.; Kieling-Rubio, M.A.; Pereira, A.F.N.; Øllgaard, B.; Ramos, C.G.V.; Mickel, J.T.; Dittrich, V.A.O.; Mynssen, C.M.; Schwartsburd, P.B.; Condack, J.P.S.; Pereira, J.B.S.\& Matos, F.B. Diversity of ferns and lycophytes in Brazil. Rodriguésia 66: 1073-1083.

Prance, G.T. 1977. Floristic inventory of the tropics: where do we stand? Annals of the Missouri Botanical Garden 64: 659-684.

Prata, A.P.N.; Amaral, M.C.E.; Farias, M.C.V. \& Alves, M.V. 2013 (orgs.). Flora de Sergipe. Vol. 1, 592p.

Pugliesi, L. \& Rapini, A. 2015. Tropical refuges with exceptionally high phylogenetic diversity reveal contrasting phylogenetic structures. International Journal of Biodiversity. 758019p. DOI: http:// dx.doi.org/10.1155/2015/758019.

Queiroz, L.P. 2009. Leguminosas da Caatinga. Universidade Estadual de Feira de Santana, Feira de Santana. 467p.

Reflora Virtual Herbarium 2015. Available at $<$ http:// reflora.jbrj.gov.br/>. Access on 9 May 2015.

Reis, A. 1996-2005 (ed.). Flora Ilustrada Catarinense. Herbário Barbosa Rodrigues, Itajaí. Avaiable at <http://hbriai.webnode.com.br/products/ enciclopedia-flora-ilustrada-catarinense-fic/ $>$. Access on 15 May 2015. 
Reitz, R. 1965-1989 (ed.). Flora Ilustrada Catarinense. Herbário Barbosa Rodrigues, Itajaí. Avaiable at $<$ http://hbriai.webnode.com.br/products/ enciclopedia-flora-ilustrada-catarinense-fic/>. Access on 15 May 2015.

Shepherd, G.J. 2003. Avaliação do estado do conhecimento da diversidade biológica do Brasil: plantas terrestres versão preliminar. Ministério do Meio Ambiente, Brasília. 60p.

Soares, K.P.; Longhi, S.J.; Neto, L.W. \& Assis, L.C. 2014. Palmeiras (Arecaceae) Rio Grande do Sul, Brasil. Rodriguésia 65: 113-139.

Sobral, M. \& Stehmann, J.R. 2009. An analysis of new angiosperm species discoveries in Brazil (19902006). Taxon 58: 227-232.

ter Steege, H.; Pitman, N.C.A.; Sabatier, D.; Baraloto, C.; Salomao, R.P.; Guevara, J.E.; Phillips, O.L.; Castilho, C.V.; Magnusson, W.E.; Molino, J.-F.; Monteagudo, A.; Nunez Vargas, P.; Carlos Montero, J.; Feldpausch, T.R.; Coronado, E.N.H.; Killeen, T.J.; Mostacedo, B.; Vasquez, R.; Assis, R.L.; Terborgh, J.; Wittmann, F.; Andrade, A.; Laurance, W.F.; Laurance, S.G.W.; Marimon, B.S.; Marimon, B.-H.; Guimaraes Vieira, I.C.; Amaral, I.L.; Brienen, R.; Castellanos, H.; Cardenas Lopez, D.; Duivenvoorden, J.F.; Mogollon, H.F.; de Almeida Matos, F.D.; Davila, N.; Garcia-Villacorta, R.; Stevenson Diaz, P.R.; Costa, F.; Emilio, T.; Levis, C.; Schietti, J.; Souza, P.; Alonso, A.; Dallmeier, F.; Duque Montoya, A.J.; Fernandez Piedade, M.T.; Araujo-Murakami, A.; Arroyo, L.; Gribel, R.; Fine, P.V.A.; Peres, C.A.; Toledo, M.; Gerardo, A.A.C.; Baker, T.R.; Ceron, C.; Engel, J.; Henkel, T.W.; Maas, P.; Petronelli, P.; Stropp, J.; Eugene Zartman, C.; Daly, D.; Neill, D.; Silveira, M.; Rios Paredes, M.; Chave, J., de Andrade Lima, D.; Jorgensen, P.M.; Fuentes, A.; Schoengart, J.; Cornejo Valverde, F.; Di Fiore, A.; Jimenez, E.M.; Penuela Mora, M.C.; Fernando Phillips, J.; Rivas, G.; van Andel, T.R.; von Hildebrand, P.; Hoffman, B.; Zent, E.L.; Malhi, Y.; Prieto, A.; Rudas, A.; Ruschell, A.R.; Silva, N.; Vos, V.; Zent, S.; Oliveira, A.A.; Cano Schutz, A.; Gonzales, T.;
Nascimento, M.T.; Ramirez-Angulo, H.; Sierra, R.; Tirado, M.; Umana Medina, M.N.; van der Heijden, G.; Vela, C.I.A.; Vilanova Torre, E.; Vriesendorp, C.; Wang, O.; Young, K.R.; Baider, C.; Balslev, H.; Ferreira, C.; Mesones, I.; Torres-Lezama, A.; Urrego Giraldo, L.E.; Zagt, R.; Alexiades, M.N.; Hernandez, L.; Huamantupa-Chuquimaco, I.; Milliken, W.; Palacios Cuenca, W.; Pauletto, D.; Valderrama Sandoval, E.; Valenzuela Gamarra, L.; Dexter, K.G. \& Feeley, K. 2013. Hyperdominance in the Amazonian tree flora. Science 342: 325. DOI: 10.1126/science. 1243092 .

Thiers, B. [continuously updated]. Index Herbariorum: a global directory of public herbaria and associated staff. New York Botanical Garden's Virtual Herbarium. Available at $<$ http://sweetgum.nybg. org/ih/>. Access on 15 May 2015.

Thomas, W.W. 2005. Flora Neotropica-Monographs as Inventories. In: Species plantarum 250 years: proceedings of the species plantarum symposium held in Uppsala August 22-24, 2003. Acta Universitatis Upsaliensis, Symbolae Botanicae Upsalienses 33:187-192.

Thomas, W.W.; Forzza, R.C; Michelangeli, F.A.; Giulietti, A.M. \& Leitman, P.M. 2012. Large-scale monographs and floras: the sum of local floristic research. Plant Ecology and Diversity: 5: 217-223.

Trias-Blasi, A. \& Vorontosova, M. 2015. Botany: plant identification is key to conservation. Nature 521: 161.

Urban, I. 1906. Index Familiarum. In: Martius, C.P.F. von. Flora Brasiliensis. Karl W. Hiersemann, Munich \& Leipzig. Vol. 1, pars 1, pp. 239-268.

Wanderley, M.G.L.; Shepherd, G.J.; Martins, S.E., Estrada, T.E.M.D; Romanini, R.P.; Koch,I.; Pirani, J.R.; Melhem, T.S.; Harley, A.M.G.G.; Kinoshita, L.S.; Magenta,M.A.G.; Longhi Wagner, H.M.; Barros, F.; Lohmann, L.G.; Amaral, M.C.E.; Cordeiro, I.; Aragaki, S.; Bianchini, R.S. \& Esteves, G.L. 2011. Checklist das Spermatophyta do Estado de São Paulo, Brasil. Biota Neotropica 11: 193-390. Available at $<$ http://www.biotaneotropica.org.br/ $>$. Access on 5 June 2015. 
